\title{
Book Review - Creating Innovators
}

Review sách: Khai sinh nhà đổi mới - Tony Wagner, 20121

Hoàng Anh Đức

Ngày nay, chúng ta thấy sự xuất hiện của từ đổi mới với tần suất dày hơn trên các phương tiện thông tin đại chúng, ở tất cả các lĩnh vực từ giáo dục, kinh tế tới chính trị, thậm chí cả giải trí. Thế nhưng, một nghịch lý đáng buồn là những nhà sáng tạo nổi danh đều trở thành nhà sáng tạo một cách ngẫu nhiên, thậm chí có phần hú hoạ, thay vì được đào tạo một cách bài bản trong trường lớp. Nghịch lý này liệu sẽ còn tồn tại bao lâu và có trở nên phức tạp hơn nữa?

Khai sinh nhà đổi mới (tên gốc "Creating Innovators") là một cuốn sách hay về chủ đề giáo dục. Nếu bạn đã quá nhàm chán với những câu hỏi muôn đời như: "Làm thế nào để học sinh vào được trường đại học tốt nhất?", hay "Làm thế nào để các em có được nghề nghiệp tốt nhất?", cuốn sách này hứa hẹn sẽ mang lại điều thú vị Tony Wagner đã quan sát những ngành nghề không có sự đổi mới, và thấy rằng chúng rất dễ bị tự động hoá. Vậy, tại sao ta lại mất công để học trò phải chuẩn bị cho những thứ dễ bị thay thế trong phút chốc? Thay vì thế, hãy giúp chúng trở thành những người đổi mới.

Tony Wagner là học giả đầu tiên tại Trung tâm Công nghệ và Khởi nghiệp (Technology and Entrepreneurship Center) của Đại học Harvard. Ông có một vài tựa sách về giáo dục, trong số đó, "The Global Achievement Gap" và "Creating Innovators" phù hợp để tương hỗ nhau bởi những chủ đề vĩ mô, đa góc cạnh nhưng chi tiết.

Nhà đổi mới là thuật ngữ mà Tony dùng để chỉ những người có khả năng sáng tạo. Đề cập đến việc đào tạo ra các nhà đổi mới, ông đã mô tả một cuộc khủng hoảng ở hầu hết các quốc gia: Nền giáo dục cần thích nghi với sự thay đổi của xã hội, do đó, luôn luôn phải đổi mới, sáng tạo. Từ đó, Tony đưa ra quan điểm của mình một cách có hệ thống, khám phá những gì mà cha mẹ, giáo viên và cả những người sử dụng lao động cần phải làm để phát triển năng lực của những người trẻ tuổi, nuôi dưỡng họ thành những nhà đổi mới. Phương châm mà Tony đề ra không phải quá xa lạ mà ngày càng hiện hữu thường xuyên hơn: "Thay vì tập trung vào các phương thức sản xuất công nghiệp (mà xuất phát điểm là các bài kiểm tra chuẩn hoá), ta nên đầu tư nhiều hơn vào việc tạo ra niềm vui, niềm đam mê và mục đích trong cuộc sống cho người học".

Cuốn sách không nhằm tạo ra kiến thức mới. Bằng việc phỏng vấn các nhà đổi mới, nhà lãnh đạo, nhà tư tưởng và cả những nhà giáo đang tiếp xúc với sự đổi mới trong trường học, Tony đưa vào từng trang sách sứ mệnh khơi nguồn cảm hứng để tạo đổi mới ở bất cứ đâu, với bất kỳ ai. Tại sao đổi mới lại quan trọng với các quốc gia, các tổ chức, và cả từng cá nhân? Chúng ta có thể tham gia vào quá trình đổi mới ngay từ bây giờ bằng cách nào? Câu trả lời sẽ được tìm thấy trong cuốn sách, thông qua câu chuyền từ những nhà đổi mới mà Tony đã tiếp xúc, như: Annamarie Neal (Giám đốc Phát triển tài năng, Phó Chủ tịch Trung tâm Lãnh đạo Cộng tác Cisco), David Kelley (Nhà Sáng lập IDEO và Trường Thiết kế Stanford), Joost Bonsen (Giảng viên tại $P$

1 Wagner, T. (2012). Creating innovators: The making of young people who will change the world. Simon and Schuster. 
Phòng nghiên cứu Truyền thông Đa phương tiện tại MIT), David Edwards (Sáng lập Phòng nghiên cứu Chuyển hoá ý tưởng tại Harvard).

Bên cạnh đó, cuốn sách cũng bàn luận về các mô hình vận hành, cấu trúc của trường học hiện có và thách thức chúng trong bối cảnh tương lai của sự đổi mới. Một xã hội sáng tạo liên tục sẽ trông như thế nào? Và thậm chí, chúng ta có cần đến trường học nữa không?

Tác giả đưa ra 5 thành tố cơ bản của hệ thống Giáo dục sự đổi mới (Education for Innovation), bao gồm:

1. Cộng tác thay vì ganh đua (Collaboration v/s Individual Achievement)

2. Học tập liên ngành thay vì học tập chuyên ngành (Multidisciplinary Learning v/s

Specialization)

3. Thử nghiệm và thất bại, thay vì lảng tránh rủi ro (Trial and error v/s Risk avoidance)

4. (Chủ động) Làm ra, thay vì (Thụ động) hưởng thụ (Creating v/s Consuming)

5. Động lực nội tại, thay vì động lực ngoại lai (Intrinsic vs/ Extrinsic Motivation)

Ở những trang sách tiếp theo, Tony Wagner nhấn mạnh tới chiến lược giáo dục của Phần Lan, trong đó, mục tiêu của giáo dục tại đất nước này là biến đổi quốc gia thành một trong những nền kinh tế sáng tạo nhất thế giới chỉ trong vài thập kỷ. Độc giả có thể tham khảo thêm bộ phim tài liệu được thực hiện 1 năm trước khi cuốn sách ra đời: Hiện tượng Phần Lan: Bên trong Hệ thống trường học đáng ngạc nhiên nhất thế giới (The Finland Phenomenon: Inside the World's Most Surprising School System) do chính tác giả cùng thực hiện với Bob Compton.

Nghịch lý giữa cơ chế và thực tiễn giáo dục ở các nước phát triển như Mỹ và Châu Âu không có nhiều khác biệt so với tại Việt Nam. Một mặt, người làm chính sách muốn phát triển những chương trình "chính thống" và chuẩn mực để đánh giá thành quả học tập từ mầm non tới hết phổ thông. Mặt khác, trường học cần sự đổi mới, sáng tạo, trao quyền để giáo viên chủ động đem lại những dự án thực hành và những khoá học liên ngành (hay ở ta gọi là những bài học tích hợp). Ngày nay, để khuyến khích học sinh khám phá và sáng tạo, nhà giáo cần phải thực sự chú tâm trong việc tạo ra môi trường học tập đổi mới. Thế nhưng, chúng ta cũng không thể hoàn toàn phó thác chuyện đó lên đôi vai một người thầy. Văn hoá học đường là một sự tổng hoà, và chỉ có thể được xây dựng bởi nỗ lực và cảm hứng từ cả tập thể và cộng đồng xã hội. 